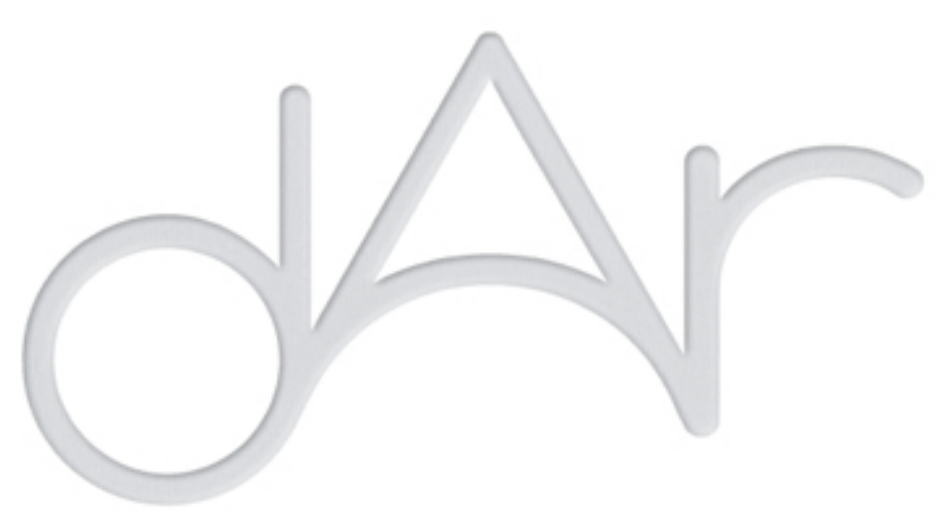

\title{
Vigencias de lo sagrado en la representación del corpus
}
Autor(es):
Tornero Sanchis, Josep
Publicado por: Centro de Estudos em Arqueologia, Artes e Ciências do Património
URL persistente:
URI:http://hdl.handle.net/10316.2/39308
DOI:
DOl:http://dx.doi.org/10.14195/2182-844X_2_13

Accessed : $\quad$ 26-Apr-2023 12:09:44

A navegação consulta e descarregamento dos títulos inseridos nas Bibliotecas Digitais UC Digitalis, UC Pombalina e UC Impactum, pressupõem a aceitação plena e sem reservas dos Termos e Condições de Uso destas Bibliotecas Digitais, disponíveis em https://digitalis.uc.pt/pt-pt/termos.

Conforme exposto nos referidos Termos e Condições de Uso, o descarregamento de títulos de acesso restrito requer uma licença válida de autorização devendo o utilizador aceder ao(s) documento(s) a partir de um endereço de IP da instituição detentora da supramencionada licença.

Ao utilizador é apenas permitido o descarregamento para uso pessoal, pelo que o emprego do(s) título(s) descarregado(s) para outro fim, designadamente comercial, carece de autorização do respetivo autor ou editor da obra.

Na medida em que todas as obras da UC Digitalis se encontram protegidas pelo Código do Direito de Autor e Direitos Conexos e demais legislação aplicável, toda a cópia, parcial ou total, deste documento, nos casos em que é legalmente admitida, deverá conter ou fazer-se acompanhar por este aviso.

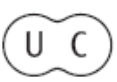




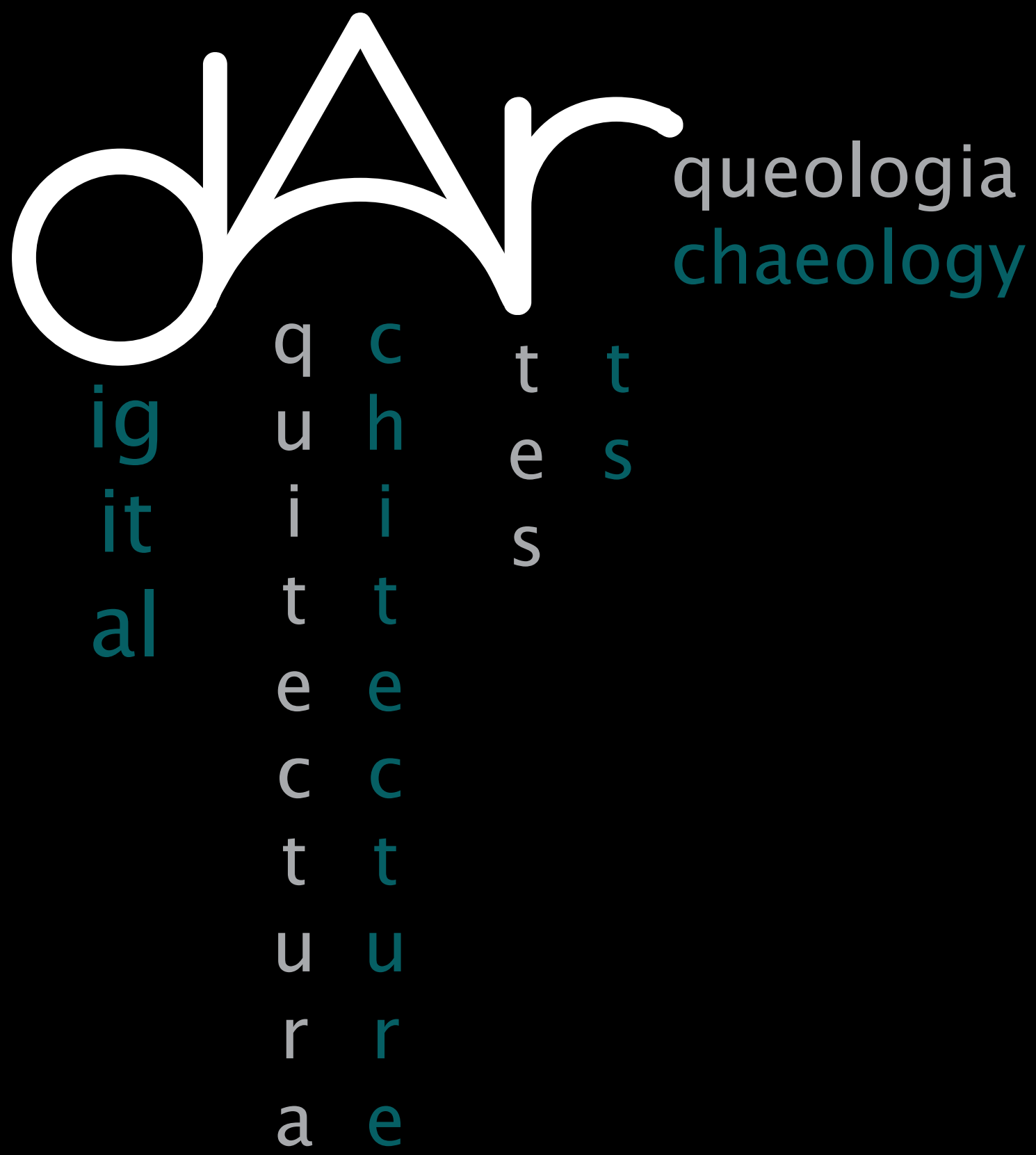




\title{
VIGENCIAS DE LO SAGRADO EN LA REPRESENTACIÓN DEL CORPUS
}

\author{
Josep Tornero Sanchis* \\ Universidad de Murcia \\ Grupo de Investigación Arte y Políticas de Identidad
}

\section{RESUMO}

El rostro y su representación se han convertido hoy en día en un problema que atiende aspectos éticos y morales, donde las artes visuales se han introducido con el ánimo de experimentar desde los parámetros de la estética sus posibilidades de representación. El presente artículo intenta aproximarse a los problemas morales y éticos de la identidad desde una psicología histórica, revisando algunos de las posibilidades representativas del cuerpo en la pintura donde podemos encontrarnos con retornos de lo sagrado, valores simbólicos que nos proponen recordar principios y responsabilidades.

Palavras-chave: sagrado, cuerpo, representación.

\begin{abstract}
The body and his representation have turned into a problem which deals with moral and ethical aspects nowadays, where the visual arts have found their way with the intention of experimenting from the parameters of the aesthetics their possibilities of representation. This article tries to approach the moral and ethical problems of the identity from a historical psychology, looking through some of the representative possibilities of the body in painting where we can find us with returns of the sacred, symbolic values which propose us remembering principles and responsibilities.
\end{abstract}

Keywords: Sacred, body, representation. 


\section{INTRODUCCIÓN}

La genealogía del cuerpo representado en las artes plásticas, unida a la genealogía de la imago, constituye un medio de transmisión cuyos valores simbólicos remiten a manifestaciones de lo sagrado: hierofanías (M. Eliade, 1998, pp. 14-15). La dificultad de la transmisión simbólica de estas hierofanías reside, como expresa el propio Eliade, en el esfuerzo y el malestar frente a lo que entenderíamos hoy por una oposición a la realidad natural. Pero la representación de un cuerpo como imago no puede sino hacer referencias, desde su propio nudo hermenéutico, a aquello de lo que de sagrado ha conformado y contextualizado el núcleo matriz que denominamos todavía como cultura occidental.

La diversidad actual en la representación del cuerpo aborda el problema de la identidad desde todo presupuesto teórico en un marco contemporáneo en el que, como anima Giorgio Agamben, se hace necesario repensar el propio concepto de identidad «de principio a fin» desde una identidad poshistórica que es una identidad sin persona, una escisión entre ambas figuras que colapsan, para el pensador, «los principios éticos personales que han regido la ética occidental por siglosı) (2011, p. 70).

Para poder abarcar una concepción más amplia del proceso de diversidad que se metamorfosea en su esencia plástica, o para definirlo junto a Didi-Huberman (2008, 2009): como el retorno de un pathos que hace estallar ante nosotros la historia de las imágenes, es conveniente volver a las investigaciones de Jean-Pierre Vernant para aproximarnos a la figura ática de Dionisos, la encarnación del otro, ya expuesta en la filosofía y en la fórmula de Nietzsche (2000). Es aquí donde surgen potencias de lo sagrado que se manifiestan en la propia alteridad dionisíaca, en el afuera del individuo a través del corpus. En esa especie de intercambios de juegos y afectos entre el griego y la deidad se aceptaba la alteridad como parte de la unidad, del sí mismo. Es decir, el dios se convierte en imagen del hombre a través del corpus, ofrece una representación desde la corporeidad, una apariencia humana, en ese flujo de semejanzas entre lo divino y lo humano (J. Clair, 1999, p. 182).

Es en esa hierofanía dionisíaca donde se realiza una responsabilidad ética y moral en el pueblo ático, donde el otro, encarnado a la vez por el sujeto y la deidad, forma parte del corpus de lo sagrado a través del rostro, de la máscara y la persona -el «personaje»-que adquiere cada uno de los entes que participan en los límites difuminados de la posesión, de la utilización de la máscara y su equivalencia a una transfiguración: la hipóstasis dios-hombreanimal. También el corpus nos devela el horror y el espanto, lo tremendum, el abismo que refleja lo Otro inefable. Abyssus abyssum invocat (el abismo invoca al abismo).

\section{EL CUERPO REPRESENTADO. HUELLAS DE UN ACCIDENTE.}

El arte, lugar donde se interpretan los diferentes escenarios de la existencia, está lleno de referencias y metáforas que aluden a la realidad; individual y colectiva, propia e impropia, a las preocupaciones del individuo y los sujetos. Lugar donde se plasma el acontecer mismo de aquello que va pasando frente a nuestra mirada e interactúa con nuestros afectos y nuestras emociones. Recopilando, como huellas de la existencia, todo aquello que nos hace ser y nos devuelve, desde una inquietante extrañeza, aquello que fuimos: abarcando un amplio contexto de preguntas y dudas, de esperas medradas y situaciones límite, de experiencias intensas y abismos a los que nos asomamos para quedar inmediatamente atrapados en la intuición trágica del devenir, acompañada de cierta desconfianza en la razón, y la certeza implacable que consigue redimirnos en la derrota: la vida es suficiente.

Recurro a la memoria, es decir, a las entrañas. Enigma e imagen -una imagen representada- tienen en común que son objeto de interpretación. Caída e irrupción. Inversión y envolvimiento. La imagen representada, vuelta a presentar, tiene «el carácter de un juego - perturbador- con la 
memoria») (Georges Didi-Huberman, 2008, p. 151).

Pintura y escultura son imágenes supervivientes porque no existen en un tiempo a priori, limitado a la línea o acción de un presente concreto, sino que tienen $-\mathrm{y}$ quizás de ello depende su supervivenciaun carácter dado de no-presencia.

Esta no-presencia implica, desde el torbellino de lo acontecido, una puerta abierta a los nervios y fisuras que presentan las imágenes; no como espejos donde creemos mirarnos intentando reconocernos. No sólo cercando un origen, más allá de nosotros mismos y más allá de la propia imagen representada. Esta implicación, esta fisura, esta fractura de una interpretación de las mismas se produce desde una genealogía de las imágenes o desde una "exterioridad del accidente» (Foucault, 2008, p. 28) que acontece en la representación contemporánea del cuerpo.

Lo que nos concierne en nuestro caso no es trazar, re-trazar, una genealogía de las imágenes, ni una genealogía de la historia del arte, o de la filosofía, pero sí recurrir a ella, de modo que podamos escarbar para poder interpretar a costa de las imágenes representadas un atisbo de empatía, un pathos que, en líneas generales, no muestra «que el pasado está aún ahí, bien vivo en el presente» (Foucault, 2008, p. 27), sino que nos devuelve la paradoja de una fractura que atañe a la historia de las imágenes. El pathos no hace retornar la idea original de una obra, el origen por lo que fue creada. En cambio ¿habría una memoria que habla directamente a los sentidos, al cuerpo? y en todo arte ¿̇habría una imagen -una imagen representada- cuya vitalidad, aun sin ser verdadera, es suficientemente intemporal pudiendo ser, de esta o alguna otra forma, capaz de transmitir y capaz de crear interpretaciones desde esa fractura de la historia?

La apuesta reside en que todo arte nace de una necesidad fisiológica, por lo que conserva cierta fuerza vital que transmite, a modo de memoria, a modo de susurro; y atañe a todo aquello que tiene que ver con los afectos - esos pequeños monstruos que nos arrastran en exceso- a los sentidos, a lo pensado -y este pensar ya está incluido en esa comunicación de los instintos entre sí. Y por ende, al cuerpo. En este sentido cabría preguntarse, de nuevo, si la relación de semejanza de una imagen figurativa, cuerpo o retrato, obedece a un orden epistemológico cerrado, o por el contrario, esa relación de semejanza abarca un sentido más amplio, y corresponde a diferentes puntos de fuga, a diferentes interpretaciones, que conservan la «exterioridad del accidente» que de algún modo les dio origen.

En este sentido, las diferentes representaciones del cuerpo podrían devenir en conducto de transmisión de una memoria, que contiene aspectos de lo sagrado, desde la observación de la apariencia misma, obviando conceptos a la postre añadidos; pues el cuerpo y su representación ya encierran en sí aquello que dejan ver; algo a lo que Heidegger dio en llamar la historia del ser. Entraríamos en la delimitación de una memoria del cuerpo que atañe al cuerpo, cuya transmisión se produce por él y su sentido de pluralidad de fuerzas que actúan como voluntad; pensamiento, sentidos, instintos, deseos, anhelos, ansia, destrucción, tragedia.

De esta manera, podemos interpretar desde un posible pathos - desde la empatía que provoca y deviene en una memoria-, desde nuestras entrañas mismas, estigmas y señales de acontecimientos pasados, donde devienen y se crean -como en el juego inocente del niño- deseos, debilidades y errores. En el cuerpo se encuentra la lucha y la separación, y también los nudos que van configurando la creencia en cierta unidad, la certeza de cierta unidad, e incluso la nostalgia de su falta. Conflictos todos ellos que se anulan y prosiguen en un vínculo entre lo mortal y lo divino, entre la ausencia y la presencia, que permiten el devenir del ser, un eterno devenir del ser. Interpretaríamos, desde este pathos, desde la memoria - como si de una especie de cordón umbilical se tratara-, una transmisión enigmática, una empatía disgregada, diseminada, en esa especie de 
cortocircuito que estalla y que se produce en el espacio-tiempo; fractura de la mirada que, desde el presente, deviene en fractura de la historia misma, sin temor a no poder encontrar una verdad originaria a la que poder achacar desvíos y cobardías desde un origen -en un sentido socrático-, porque «es el cuerpo el que lleva, en su vida y su muerte, en su fuerza y su debilidad, la sanción de toda verdad y de todo erronı (Foucault, 2008, p. 31).

\section{TRANSMISIÓN Y SÍMBOLO. UN NEXO TEOLÓGICO.}

En la historia de las imágenes de Occidente, el cuerpo de Cristo acontece como el emblema de toda representación. Es en su hipóstasis de Hombre-Dios, Verbo y carne, donde accedemos a uno de los nexos teológicos más evidentes con la representación de un cuerpo. La hipóstasis reaparece en el cuerpo representado con pigmentos como carne deificada y materia sublimada, en conexión directa con el concilio de Calcedonia (451), donde se proclama el código de la Encarnación. Del Hombre-Dios a la pintura encarnada se tiende el puente de dos milenios de cultura occidental.

Nexo teológico que, además, confluye ante el tiempo en el torbellino de imágenes en una historia común, anclada en la huella de la Anunciación-Encarnación, del Verbo hecho carne que la Iglesia de la Contrarreforma se ocupará de reducir, por así decirlo, en el intento de evitar el problema de la dimensión humana de Cristo frente a la reciente escisión protestante. Curiosa historia de un cuerpo sin presencia en el que sólo se puede atisbar su vacío, en una «Kenosis continuada», cuyo "vaciamiento de la presencia» contiene el brillo de la luz (Jean-Luc Nancy, 2006, p. 44). Vacío que brilla en la ausencia del cuerpo, en la ausencia misma de la huella, de su paso, del accidente de lo sagrado hecho carne. Nexo de unión de lo acontecido y el propio devenir, que nuevamente nos permite reflexionar ante el cuerpo representado, ante su vacío, ante la paradoja fantasmagórica de una presencia-ausencia como transmisión simbólica.

El cuerpo sagrado, lo Humano-Divino; transvaloración de valores en las apariencias mismas, en el intento de representación de un cuerpo que acaba siendo un vínculo con el pasado, a modo de fragmentación de la historia y del tiempo de las propias imágenes, inmersa en esa "arqueología crítica» (G. Didi-Huberman, 2008 , p. 33) que no es posible sin un anacronismo de éstas.

El cuerpo sagrado del Hombre-Dios une, reúne junto a la imagen, hace encontrarse con el símbolo, en ese instinto de perdurar. En este sentido, para que el cuerpo sagrado ejerza como objeto simbólico ha de ponerse éste en paralelo a otro, en relación con otro. Régis Debray utiliza las siguientes definiciones, donde simbólico será, en primer lugar, todo objeto que sirve de nexo de unión entre un individuo y otro, o una comunidad de individuos y otra; en segundo lugar, como cuerpo o idea que lanzará una realidad visible junto a otra invisible, ya sea en una unidad temporal o en diferentes estadios de la historia, del pasado y el futuro (R. Debray, 2001, p. 49).

De nuevo, Debray, en Vida y muerte de la imagen, nos explica el significado etimológico la palabra símbolo. Symballein (sumb£llein) está compuesta por las voces sym (sum): juntar, y ballein (b£llein): lanzar, arrojar, tirar. Es decir, lanzar conjuntamente: reunir, poner junto, acercar. Signo de reconocimiento, simbólico y fraternal se encargan de compartir, de unir. Lo que separa, lo que divide, es en griego el antónimo de sim-bólico, el diablo: Diabólico (diab£llein) (R. Debray, 2001, p. 51).

El símbolo pondrá en común, acercará nuestra mirada a la que ya ha sido lanzada desde otro, desde el otro. El cuerpo representado será un vínculo con nuestra memoria, desde la huella, desde la impronta. Vínculo y unión de diferentes valores simbólicos de la historia de la mirada, significantes cargados con el peso hermenéutico donde algún mito todavía puede susurrarnos al oído. Quizás, es aquí donde se obra el milagro del 
arte, donde se aborda el continente del «transmitin», trascendiendo lo propio de la «comunicación», del sentido inmediato.

Si alguna vez se privilegió la lengua hablada, la palabra, no es más simbólico ésta que la piedra o la arcilla. La transmisión simbólica en un cuerpo representado ha de centrarse en la huella, la impronta; algo que nos obliga a proceder a contrapelo. En los distintos valores simbólicos de un cuerpo representado se exterioriza una interioridad. De alguna manera, monumentaliza. Explicaremos mejor al advertir que Monumento, del latín monumentum, contiene la raíz indoeuropea men-, presente en el verbo monere: recordar, también advertir, alertar. En men- presente también en mens (mente), o memoriaencontraremos más de un sentido: estimulación del recuerdo, el compromiso de alguien a llevar a cabo algo y, por último, la predicción de un imprevisto.

El cuerpo representado actúa como un accidente en la historia y el tiempo, y su visión implica un movimiento que se produce en nuestra memoria. Del cuerpo representado al cuerpo sagrado; y de ahí y a la vez, al origen, a las primeras estelas levantadas en las tumbas, a los primeros intentos figurativos de cuerpos esculpidos en piedra o tallados en la madera.

Para Debray, la transmisión simbólica del monumento, de la piedra-objeto — del objeto-símbolo- equivaldría lo que la palabra a una lengua: «El monumento sería entonces al pensamiento de un colectivo lo que la palabra, enunciación físicamente sensible, es a la lengua, totalidad inteligible aunque abstracta» (R. Debray, 2001, p.45).

Recuperar los sustratos más sólidos de nuestra cultura equivale a distinguir lo simbólico del símbolo. En la historia de las artes se puede simbolizar la experiencia de otros modos que no pasan por la palabra, donde el discurso no es más que un medio de expresión, entre otros, del pensamiento. En consecuencia, la distinción pasa porque la palabra comunica, mientras que la piedra transmite. Si el cuerpo esculpido simboliza, lo simbólico podrá extraerse de éste, como podrá extraerse de la imagencuerpo.

De este modo, la tumba es, para Debray, el signo con el que se conectan nuestra memoria y nuestros orígenes. De nuevo, para despejar las incógnitas debemos volver a las raíces: signo proviene del griego sema, el cual significó originariamente tumba, la columna de piedra que señala al muerto. Más tarde, el kolossos, que será el doble del difunto: el artificio de un signo figurativo. Por último, el signo escrito; grafías y alfabetos. Si uel arcaísmo funerario produce en nosotros un efecto lupa», materializar un valor simbólico «o monumentalizar es siempre, en mayor o menor medida, hacer grupo, hacer lugar, hacer duran» (R. Debray, 2001, p.46).

\section{EL CUERPO EN LA MUERTE. LA REPRESENTACIÓN DE LO INVISIBLE.}

«Nacimiento y escisión irreversible, el "doble" es el enigma de la representación» (R. Martínez-Artero, 2004 , p.35). Será este doble por el cual el valor simbólico del eidôlon, del fantasma del muerto, se manifiesta ante el griego arcaico. Una manifestación de su ausencia, podríamos decir, y por lo tanto, de un deseo de perdurar, materializándose en el ídolo.

La categoría psicológica del doble nos muestra «cómo los griegos han podido expresar en una forma visible poderes del más allá que pertenecen al terreno de lo invisible») (Jean-Pierre Vernant, 2001, p.302). Según Vernant, «la naturaleza de estos poderes sagrados se halla estrechamente ligada a su modo de representación» (ibíd.). Recordemos que en todo sistema simbólico, el artificio de las formas, la figuración, y por lo tanto la representación, constituyen su medio de transmisión. En la historia de la mirada, la figuración forma parte del aprendizaje de nuestra cultura.

En este sentido, la genealogía de la imagen nos remite al reflejo, en Narciso, y a la sombra (en el relato de Plinio), y ésta es el nombre común del doble. Pero, para revisar una ontología de la imagen del cuerpo, para desenvolvernos en ese nudo 
hermenéutico, consideraremos el ejemplo elegido por Vernant para tratar el doble y su categoría psicológica. Éste no es otro que los Kolossoi, la piedra funeraria que señala la tumba, el signo de una ausencia que la piedra dota de presencia.

En los orígenes kolossos no hace referencia, como indica Vernant, a un objeto o efigie de dimensiones "colosales". De su raíz kol-, se atribuye a ciertos lugares del Asia Menor (Kolossai, Kolofon, Kolura), y su significado hace referencia a la idea de erigir o alzar, ya sea un objeto, un tronco, un altar.

A diferencia de ídolos como el bretas o el xoanon, que se presentan siempre en procesiones o en brazos de sacerdotes y sacerdotisas, el kolossos se define por su inmovilidad, por su fijación al suelo.

Según explica Vernant, en la antigua Midea fue encontrado un cenotafio del siglo XIII a. C. En lugar de los restos humanos que se pensaba iban a ser hallados, «dos bloques de piedra que yacían en el suelo, uno más grande que otro, burdamente tallados en forma de losas cuadrangulares estrechándose hacia lo alto para marcar el cuello y la cabeza de personajes humanos (un hombre y una mujer)» (ibíd.).

Como bien indica Vernant, conocemos estas prácticas de substitución. Los antiguos griegos creían que el cadáver de un hombre desaparecido, sobre el que no se hayan podido «cumplir sobre él los ritos funerarios» (ibíd., p.304), oculta un poder peligroso, ya que no ha sido relegado al Hades y por lo tanto su doble, su sombra o su psyché, vaga entre los mundos de los vivos y los muertos. En llíada, la sombra, el espectro, el eidôlon de Patroclo implora a Aquiles que cumpla con los ritos funerarios:

«Estás durmiendo y ya te has olvidado de mí, Aquiles.

En vida nunca te descuidaste, pero sí ahora que estoy muerto.

Entiérrame cuanto antes, que quiero cruzar las puertas del Hades.

Lejos de sí me retienen las almas, las sombras de los difuntos,

que no me permiten unirme a ellas al otro lado del río, y en vano vago por la mansión, de vastas puertas, de Hades.l) (Homero, 2000, XXIII, 70 y ss.)

En el origen, la magia de la imagen profiláctica sustituye al difunto y calma a las sombras de los muertos, dejando en paz a los vivos si éstos no les descuidan. En la magia del origen, el kolossos no es una imagen, sino el doble. Sombra del muerto, no es la imagen del difunto lo que la piedra encarna, sino su fantasma, su espectro, el eidôlon en su nueva esfera mitológica. Allí donde se erigía una columna de piedra, en cenotafios o bosques, «se celebraban los ritos de la evocación del muerto») (Cfr. Vernant, 2001, p.304).

Las primeras representaciones antropomorfas esculpidas en la piedra realizan, desde los orígenes arcaicos de nuestra cultura, la transmisión simbólica del enunciado sempiterno de la presenciaausencia y la perdurabilidad de la huella. Inmutable, el arte no cesará de imprimir rasgos, de figurar, creando imágenescuerpo que simbolizan lo divino por lo humano en esa presencia insólita que es también, como indica Vernant, el signo de una ausencia.

En cuanto a imagen profiláctica, no sólo preserva sino que además es benéfica porque es simbólica (R. Debray, 1998, p. 53.). A través del kolossos el difunto se presenta a los vivos, haciendo patente su presencia. Es decir, la imagen se «abre a una cosa distinta de sí misma» (ibíd., p. 54). Para Debray, es aquí donde aparece lo sagrado, en esa apertura a un aspecto distinto.

\section{IMAGEN Y CUERPO. UNA KENOSIS CONTINUADA.}

Si la huella de un accidente, reflexión con la que comenzamos este breve ensayo, puede ser transmitida desde los sustratos de la cultura a través del cuerpo, y por ende, en modo de una historia del ser cuya única verdad reside en el pathos mismo de la imagen, en su poder de transmisión, en su capacidad de empatía, no podemos más que atender a las razones del cuerpo pintado, imagen materia e imagen cuerpo, 
capaz de sobrevivir a nuestro tiempo seguramente por su capacidad de decir no, de transmitir no.

La pintura es el cuerpo de la imagen, y ese cuerpo sobrevive en nuestro tiempo a través el accidente mismo, huella inmutable de un vacío sagrado, de su vaciamiento, singular y fragmentado, que resiste a base de pigmentos encarnados mostrando sus heridas más patentes. Tal y como advertíamos anteriormente, la pintura es el cuerpo de la imagen, y al igual que un cuerpo glorioso, nos impide estar en él, pues su verdad no es otra que la ausencia, el cuerpo como vacío, mostrando lo sagrado en su vaciamiento, mostrándose a través de esa Kenosis continuada que pensara Nancy, como una verdad parabólica y cuyo logos se muestra, pues uno es distinto de la figura o de la imagen, puesto que su contenido esencial es precisamente que el logos se figura, se presenta y se representa» (JeanLuc Nancy, 2006, p. 10).

Son las imágenes quienes tienen la capacidad de introducir lo invisible, es en ellas donde el "logos se figura» y sirven de vehículo de transmisión de lo inaprehensible, de aquello distinto, donde el mito todavía tiene su espacio-tiempo en el que perdura; pues este logos que se presenta «permite ver algo» (M. Heidegger, 2000 , p. 43). Recordemos que logos corresponde al verbo lšgein, el cual significa «decin», «hablan», pero en su sentido más originario, también significa «escogen», «reunin», sentido que prevalece en la voz latina legere. Lšgein, ureunin», es uponer una cosa junto a otra», «com-poner» no de un modo aleatorio, sino, más bien al contrario: seleccionar, diferenciar, discernir, cualificar. De algún modo, lo simbólico está estrechamente ligado al lógos, pues ambos reúnen, com-ponen y permiten ver en la ausencia, en el vacío, aquello que perdura.

\section{CONSIDERACIONES SOBRE EL CUERPO Y LO SAGRADO EN LA PINTURA CONTEMPORÁNEA.}

Partiendo del título de nuestro ensayo, ha sido nuestra intención desde el principio presentar en un breve análisis teorías con las que afrontar el estudio del cuerpo representado y las posibles vigencias de lo sagrado, o de aspectos de lo sagrado, que pueden permanecer en representaciones contemporáneas.

Estas vigencias han sido expuestas atendiendo a un nexo común: la transmisión de lo simbólico a partir de la representación del cuerpo y su enigma como imagen, en

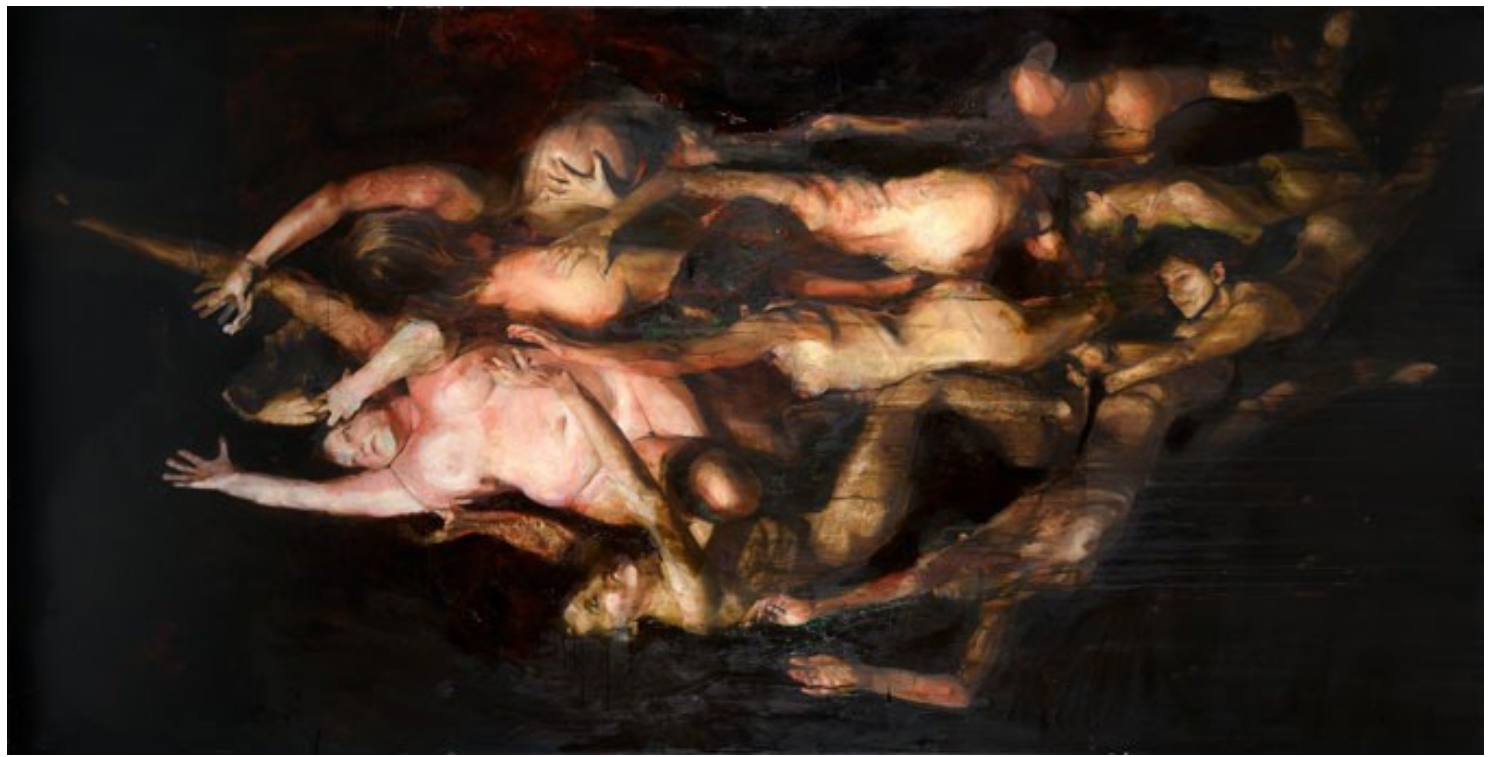

Fig.1 - Roberta Coni, Enno Dannatti i Peccator Carnali. Óleo sobre tela, 120 × 300cm, 2012. 


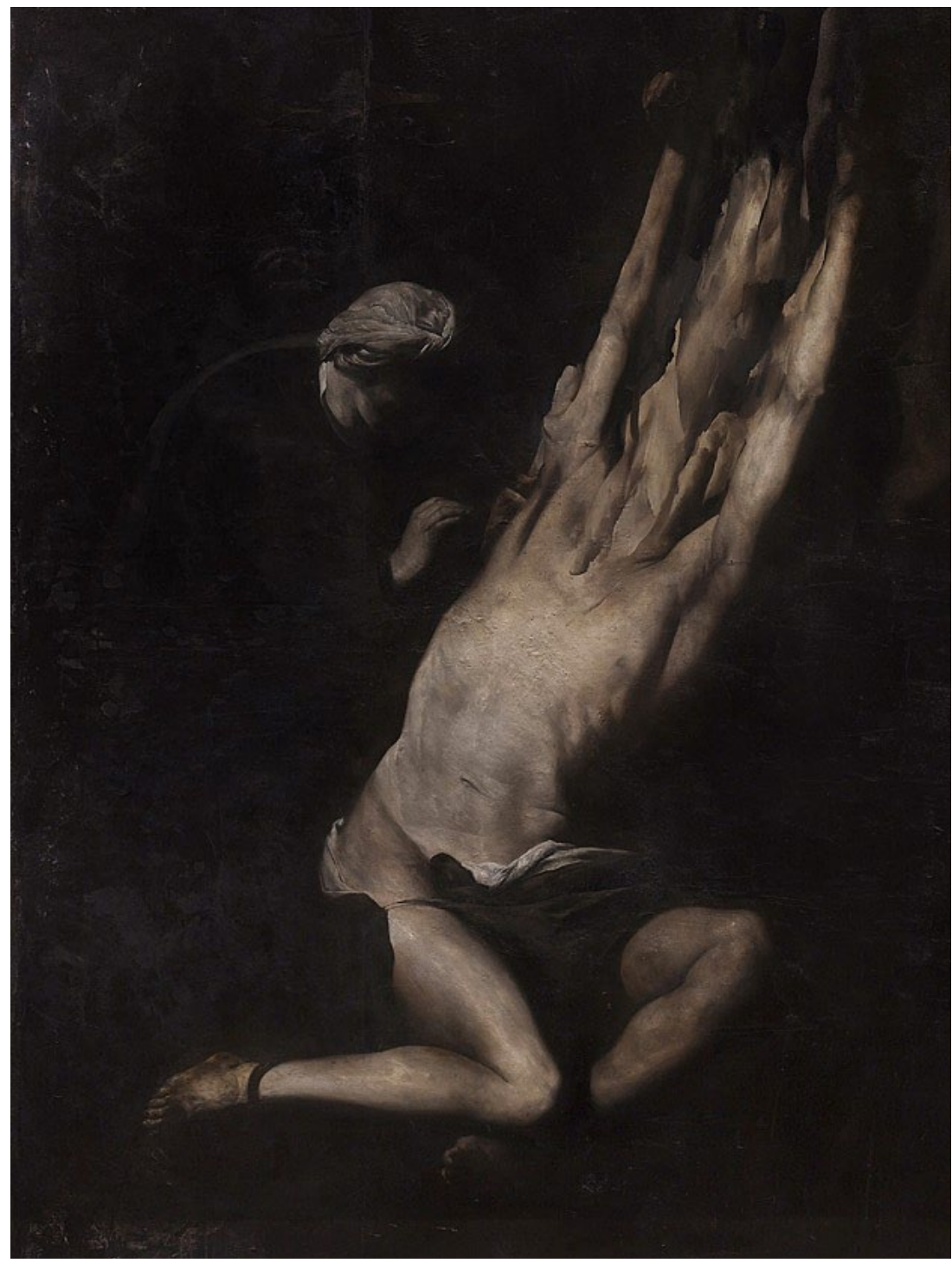

Fig.2 - Nicola Samorì, Irene scopre l'Informale. Óleo sobre tela, 200 x 150 cm, 2012.

ese aspecto de lo sagrado por la que una imagen es capaz de mostrar algo diferente, lo intangible que sólo la mirada puede develar o, al menos, intuir. «Se trata siempre del mismo acto misterioso: la manifestación de algo completamente diferente, de una realidad que no pertenece a nuestro mundo, en objetos que forman parte integrante de nuestro natural, profano. (M. Eliade, 1998, p. 15).

Hemos querido señalar, de esta forma, la relación estrecha que unen cada una de las representaciones actuales del cuerpo con elementos simbólicos que registramos desde los orígenes de nuestra cultura. $\mathrm{O}$ mejor dicho, hemos iniciado nuestro ensayo exponiendo algunos de los elementos simbólicos partiendo desde los sustratos de la cultura, elementos simbólicos de una vigencia notable que hayamos en la producción de obras contemporáneas.

Las vigencias de lo sagrado en la pintura contemporánea se dan desde el intento de negación por ser imagen, o por ser únicamente imagen. La pintura acepta ser cuerpo, materia, volumen y despojo. Es la carne de la imagen, el cuerpo del fantasma que persiste a base de evocación 


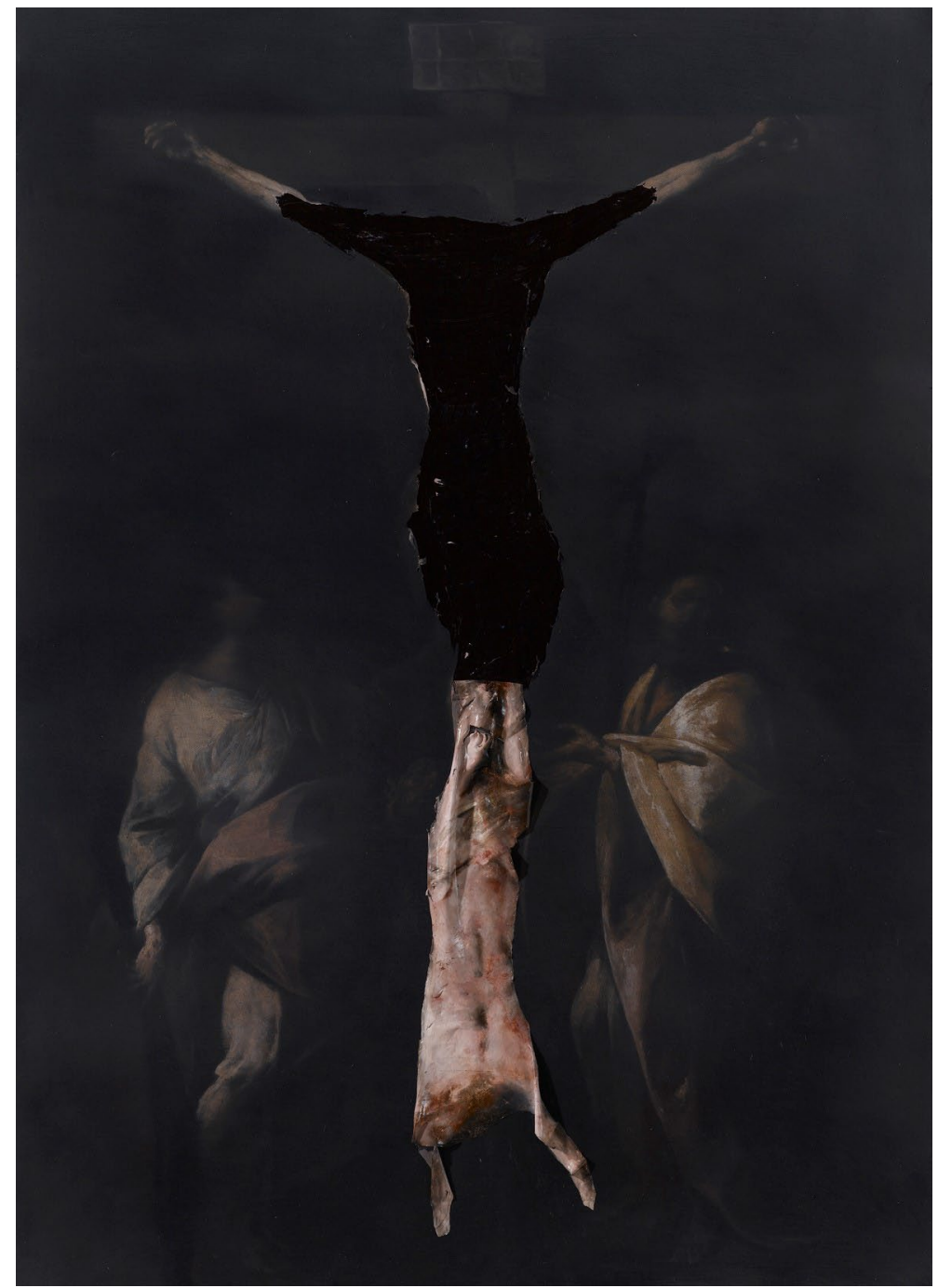

Fig.3 - Nicola Samorí. Reverso, óleo sobre tabla. 70 x 50 cm. 2010.

y transmisión. La pintura sobrevive a base de pigmentos encarnados y de lacas que sangran, ante nuestra mirada, como las heridas abiertas del Ecce Homo, de Tizio o Prometeo, o desde el desgarro de las almas con cuerpo que son torturadas en el Inferno de Dante (fig. 1). El mito persiste, su susurro nos llega a través de la imagen corpórea, de la imago-corpus; cuerpo o despojo de lo fantasmagórico. Su lógos reúne, pone en común ambos enigmas, mostrándolos a la mirada a través de su vacío.

Nicola Samorì incide con sus imágenes, una y otra vez, sobre el cuerpo matérico de la imagen pintada, también de la imagen inmersa en el torbellino del tiempo que retorna, a base de ser disuelta, diluida (fig. 2). Se evoca, de esta forma, el deseo de persistir, de seguir siendo cuerpo a través de una imagen con cuerpo. Pero en sus obras transciende también este hecho, el de ser únicamente una imagen materia. Transciende rasgando las telas, despellejando las carnes representadas, re-presentándonos de nuevo ante el vacío mismo que es una imagen, y evocando ese vaciamiento como única luz que brilla tras los pigmentos (fig. 3).

A pesar de la evidente elección de lo sagrado en las obras de Samorì, la pintura contemporánea muestra una vez tras otra el despojo matérico de la pintura como 
fenómeno sobrante, cuya plasticidad convierte a estos cuerpos representados en imágenes del tiempo, pues en ellas podemos escuchar el susurro del mito y la acción de su anacronismo en eso suyo que es el accidente y la fracturación; su huella impresa a base de negación, de vaciamiento, encerrado en el enigma propio de la imagen. Desde Bacon a Music, pasando por Lucian Freud y artistas que han desarrollado su recorrido pictórico, como Jenny Saville, se nos interroga sobre cada uno de los enigmas que el cuerpo ha encerrado en sus re-presentaciones, mostrándose a través de esa Kenosis continuada que pensara Nancy, en el ejercicio continuo de figurar un lógos que se muestra en cada uno de los cuerpos representados, cuerpo que se multiplica en su multiplicidad, a modo de hipóstasis, de transfiguración. El cuerpo es cada uno de los corpus acontecidos ante el tiempo, y el mismo. Porque la singularidad del cuerpo deviene justamente en eso, en lo único e irrepetible. Y la paradoja de la singularidad es que se repite, constantemente, sin pausa, en el movimiento unitario del espaciotiempo; allí y en todas partes.

\section{Bibliografia}

Agamben, G. (2011). Desnudez. Barcelona: Anagrama.

Clair, J. (1999). Elogio de lo visible. Barcelona: Seix Barral.

Debray, R. (1998). Vida y muerte de la imagen. Historia de la mirada en Occidente. Barcelona, Paidós Comunicación.

Didi-Huberman, G. (2008). Ante el tiempo. Historia del arte y anacronismo de las imágenes. Buenos Aires: Adriana Hidalgo Editora. (2009) La imagen supervivente. Historia del arte y tiempo de los fantasmas según Aby Warburg. Madrid: Adaba Editores.

Eliade, M. (1998). Lo Sagrado y lo profano. Barcelona: Paidós Ibérica.

Heidegger, M. (2000). El ser y el tiempo. México D. F.: Fondo de Cultura Económica.

Nancy, J.-L. (2006). Noli me tangere. Ensayo sobre el levantamiento del cuerpo. Madrid: Editorial Trotta.
Foucault, M. (2008). Nietzsche, la genealogía, la historia, Valencia: Pre-Textos.

Homero (2000). Ilíada. Madrid: Gredos.

Lévy-Strauss, C. (2007). Mito y Significado. Madrid, Alianza Editorial.

Vernant, J.-P. (2001). Mito y pensamiento en la Grecia Antigua. Barcelona: Editorial Ariel. 